\title{
AKIBAT HUKUM TIDAK DILAKUKANNYA PEMERIKSAAN SETEMPAT DALAM GUGATAN DENGAN OBJEK SENGKETA TANAH: APAKAH ADA?
} \author{
LEGAL CONSEQUENCES OF FAILURE TO CONDUCT LOCAL
} INSPECTIONS IN LAWSUITS CONCERNING LAND DISPUTE OBJECTS: ARE THERE ANY?

\section{Febrian Dirgantara}

Fakultas Hukum Universitas Airlangga

febrian.dirgantara@gmail.com

\author{
Ahmad Muzakki \\ Fakultas Hukum Universitas Airlangga \\ ooo.zakki@gmail.com \\ Joni Eko Waluyo \\ Fakultas Hukum Universitas Airlangga \\ jonismart14@yahoo.co.id \\ Xavier Nugraha \\ Fakultas Hukum Universitas Airlangga \\ xavier.nugraha-2015@fh.unair.ac.id
}

\begin{abstract}
Disputes with land objects are the most disputes in the District Courts in Indonesia. So many disputes with land objects, do not necessarily make the judge carelessly in examining the dispute, even the judge is demanded to be very careful in deciding disputes with the land object. One form of judicial caution is to conduct a local examination (gerechtelijke plaatsopneming). This local inspection is carried out to ensure that the land which is the object of the dispute is genuine, so that it is not wrong and can be executed. In its development, related to this, local inspection has been regulated in the legislation in Indonesia, but it does not have a clear position. Based on these problems, the formulation of the problem in this study is 1) What is the legal position of the local examination (gerechtelijke plaatsopneming) in the legislation in Indonesia? 2) What are the legal consequences of not doing a local inspection (gerechtelijke plaatsopneming) on a lawsuit with the object of land dispute? This research is a normative legal research with a legislative approach, conceptual approach, and case approach. Based on this research, it was found that 1) the juridical consequence of using the phrase "if deemed necessary" in the legislation relating to local examination is when one party (Plaintiff, Defendant, or Judge) has requested a local examination, then the examination is true this local is mandatory 2) Due to the law does not carry out local inspection, when there is one party who wishes is the lawsuit is not acceptable (niet ontvankelijke verklaard. The lawsuit is not acceptable, because the lawsuit is obscured (obscuur libel)
\end{abstract}

\section{Keywords: Legal Consequences; Local Inspections; Lawsuit; Land}

\begin{abstract}
Abstrak
Sengketa dengan objek tanah merupakan sengketa terbanyak di Pengadilan Negeri di Indonesia. Begitu banyaknya sengketa dengan objek tanah, tidak lantas membuat
\end{abstract}


hakim asal-asalan dalam memeriksa sengketa tersebut, bahkan hakim justru dituntut untuk sangat hati-hati dalam memutus sengketa dengan objek tanah tersebut. Salah satu wujud kehati-hatian hakim adalah dengan melakukan pemeriksaan setempat (gerechtelijke plaatsopneming). Pemeriksaan setempat ini dilakukan untuk memastikan, bahwa tanah yang menjadi objek sengketa benar-benar riil, sehingga tidak salah dan bisa dieksekusi. Dalam perkembangannya, terkait pemeriksaan setempat ini telah diatur di dalam peraturan perundang-undangan di Indonesia, namun tidak memiliki kedudukan yang jelas. Berdasarkan problematika tersebut, rumusan masalah dalam penelitian ini adalah 1) Bagaimana kedudukan hukum pemeriksaan setempat (gerechtelijke plaatsopneming) di dalam peraturan perundangan di Indonesia? 2) Apa akibat hukum tidak dilakukannya pemeriksaan setempat (gerechtelijke plaatsopneming) terhadap gugatan dengan objek sengketa tanah? Penelitian ini adalah penelitian hukum normatif dengan pendekatan pendekatan perundang-undangan, pendekatan konseptual, dan pendekatan kasus. Berdasarkan penelitian ini ditemukan, bahwa 1) konsekuensi yuridis dari digunakannya frasa "jika dirasa perlu" di dalam peraturan perundang-undangan terkait pemeriksaan setempat adalah, ketika salah satu pihak (Penggugat, Tergugat, atau Hakim) telah menghendaki adanya pemeriksaan setempat, maka sejatinya pemeriksaan setempat ini bersifat wajib 2) Akibat hukum tidak dilaksanakannya pemeriksaan setempat, ketika terdapat salah satu pihak yang mengehendaki adalah gugatan tersebut tidak dapat diterima (niet ontvankelijke verklaard. Gugatan tersebut tidak dapat diterima, karena gugatan tersebut kabur (obscuur libel).

\section{Kata Kunci: Akibat Hukum; Gugatan; Pemeriksaan Setempat; Tanah}

\section{PENDAHULUAN}

The best investment on earth is earth. ${ }^{1}$ Sebuah adagium klasik dalam bidang ekonomi yang dapat dikatakan paling tepat untuk menggambarkan kondisi dewasa ini yang notabene harga tanah selalu mengalami peningkatan setiap tahunnya. Harga tanah yang selalu mengalami peningkatan inilah yang menyebabkan setiap orang di seluruh dunia selalu berusaha untuk melakukan investasi di bidang-bidang yang berkaitan dengan tanah, seperti jual-beli properti, persewaan apartemen, dan sebagainya. Tindakan manusia yang berinvestasi dalam komoditi yang harganya selalu mengalami peningkatan ini, merupakan hal yang wajar, karena pada dasarnya manusia adalah homo economicus yang notabene selalu mencari keuntungan sebesar-besarnya. ${ }^{2}$

Begitu prestisiusnya tanah bagi setiap orang, kemudian membuat negara-negara hukum meletakkan perlindungan hak atas tanah di dalam konstitusi. Hal ini, sejatinya berawal dari teori norma berjenjang dari Hans Kelsen yang kemudian disempurnakan oleh Hans Nawiasky (die theorie vom stufenordung der rechtsnormen) yang menjelaskan, bahwa norma hukum dari suatu negara berjenjang-jenjang dan bertingkat-tingkat, sehingga norma yang dibawah berlaku dan berdasar dari norma yang lebih tinggi. ${ }^{3}$ Dengan dasar teori norma berjenjang tersebut, maka konstitusi yang notabene memiliki kedudukan tinggi dalam hierarki norma membuat negara-negara meletakkan hal-hal yang dianggap penting dan harus dilindungi ke dalam konstitusi. Gejala peletakan halhal yang dianggap penting dan harus dilindungi ke dalam konstitusi ini, acapkali disebut

\footnotetext{
${ }^{1}$ Michael Scott Doyle dan T. Bruce Fryer, 2017, Éxito commercial (Exito comercial: prácticas administrativas y contextos culturales), Cengage, Boston, hlm.134.

${ }^{2}$ Septiana Dwiputri Maharani, Manusia Sebagai Homo Economicus:Refleksi Atas Kasus-Kasus Kejahatan di Indonesia, Jurnal Filsafat, vol. 26 no. 1 edisi Februari, hlm 30-52.

${ }^{3}$ Sayyidatul Insiyah, Xavier Nugraha, Shevierra Danmadiyah, Pemilihan Kepala Daerah Oleh Dewan Perwakilan Rakyat Daerah: Sebuah Komparasi Dengan Pemilihan Secara Langsung Oleh Rakyat). Supremasi Hukum: Jurnal Penelitian Hukum, vol.28 no.2 edisi September 2019, hlm. 164-187.
} 
sebagai constitutionalization atau konstitusionalisasi ${ }^{4}$, sehingga ketika dikaitkan dengan gejala peletakan norma perlindungan hak atas tanah di dalam konstitusi ini bisa juga disebut sebagai constitutionalisation of protection of property rights. Beberapa negara yang telah meletakkan norma perlindungan hak atas tanah di dalam konstitusi ini, misalnya adalah Argentina yang mengatur di dalam Pasal 17 Konstitusi Argentina, Cambodia yang mengatur di dalam Pasal 44 Konstitusi Cambodia, Colombia yang mengatur di dalam Pasal 58 Konstitusi Cambodia, dan sebagainya.

Di Indonesia gejala peletakan norma perlindungan hak atas tanah di dalam konstitusi ini juga terjadi. Di Indonesia, pada awal mulanya di dalam UUD 1945 yang notabene merupakan konstitusi dari Indonesia tidak terdapat ketentuan terkait perlindungan hak atas tanah di dalam. Dalam perkembangannya, norma perlindungan hak atas tanah ini ditambahkan di dalam konstitusi Indonesia pada saat amandemen kedua pada tahun $2000 .{ }^{5}$ Ketentuan terkait perlindungan hak atas tanah di dalam konstitusi Indonesia, tertuang di dalam Pasal $28 \mathrm{H}$ ayat (4) Undang-Undang Dasar Negara Republik Indonesia Tahun 1945 (UUD NRI 1945) ${ }^{6}$ yang mengatur, bahwa: "Setiap orang berhak mempunyai hak milik pribadi dan hak milik tersebut tidak boleh diambil alih secara sewenangwenang oleh siapapun".

Dalam mewujudkan perlindungan hak atas tanah yang diatur di dalam Pasal $28 \mathrm{H}$ ayat (4) UUD NRI 1945 maka aturan hukum dibawahnya yang notabene merupakan konkritisasi dari UUD NRI 1945 mewujudkannya menjadi 2 (dua) bentuk, yaitu: ${ }^{7}$

1. Perlindungan hukum preventif

Perlindungan hukum preventifmerupakan perlindunganyangsifatnyapencegahan terjadinya sengketa. ${ }^{8}$ Perlindungan hukum ini bertujuan untuk mencegah terjadinya sengketa dan sangat besar artinya agar setiap orang tidak semena-mena bertindak. Dalam konteks perlindungan hukum preventif terkait hak atas tanah ini adalah untuk mencegah agarjangan sampai tanah yang notabene merupakan komoditiyang prestisius ini membuat orang yang tidak berhak mendaku bahwa tanah tersebut adalah miliknya, sehingga merugikan orang yang seharusnya berhak atas tanah tersebut. Hal ini sesuai dengan asas hukum nemo debet locupletari ex aliena jactura yang berarti tidak boleh ada seorangpun yang seharusnya diperkaya dari kerugian yang diderita oleh orang lain. Salah satu bentuk perlindungan hukum preventif terkait hak atas tanah ini, misal terkait sertipikat sebagai bentuk alat bukti kepemilikan suatu hak atas tanah bagi pemegang hak atas tanah yang bersangkutan yang diatur di dalam Pasal 4 ayat (1) jo. Pasal 3 huruf a Peraturan Pemerintah No. 24 Tahun 1997 tentang Pendaftaran Tanah

\footnotetext{
${ }^{4}$ Reva B. Siegel, The Constitutionalization of Disparate Impact - Court-Centered and Popular Pathways, California Law Review, vol. 106, No. 661 edisi Januari, hlm. 2001-2016

${ }^{5}$ Tjahyo Rawinarno, Otonomi Daerah dan "Amandemen Kedua" UUD 1945, Journal of Government, Edisi Juli, vol. 3 no. 1 edisi Juni, hlm. 281-292.

${ }^{6}$ Penggunaan frasa UUD NRI 1945 untuk menunjukan, bahwa yang dimaksud adalah UUD setelah amandemen, sementara UUD 1945 adalah UUD sebelum amandemen. Selebihnya lihat Xavier Nugraha, Risdiana Izzaty, Annida Aqiila Putri, Rekonstruksi Batas Usia Minimal Perkawinan Sebagai Bentuk Perlindungan Hukum Terhadap Perempuan (Analisa Putusan MK No. 22/Puu-Xv/2017). Lex Scientia, vol.3 no.1 edisi Mei 2019, hlm. 40-54.

${ }^{7}$ Putu Prasmita Sari dan I Gusti Ngurah Parwata, Perlindungan Hukum Para Pihak Dalam Perjanjian Bisnis Franchise, Vol. 5 No. 5 Edisi Oktober 2016, https://ojs.unud.ac.id/index.php/kerthasemaya/article/download/24613/15864, diakses pada 1 Juni 2020

${ }^{8}$ Salim HS. dan Erlies Septiana Nurbani, 2014, Penerapan Teori Hukum pada Penelitian Tesis dan Disertasi, PT Raja Grafindo Persada, Jakarta, hlm.264.
} 
(PP 24/1997). Adanya sertipikat tanah ini adalah sebagai alat bukti untuk mencegah agar jangan sampai orang yang tidak berhak dapat mendaku tanah tersebut.

2. Perlindungan hukum represif

Perlindungan hukum represif merupakan perlindungan ketika adanya sengketa. Perlindungan ini bertujuan untuk menyelesaikan sengketa yang muncul. Hal ini sesuai dengan asas hukum lex semper debitremedium, yang berarti hukum selalu memberi obat terbaik. ${ }^{9}$ Dalam konteks perlindungan hukum represif terkait hak atas tanahini, adalah untuk memulihkan hak atas tanah yang dia miliki. Salah satu bentuk perlindungan hukum represif terkait hak atas tanah ini, misal melalui gugatan perbuatan melanggar hukum (onrechtmatigedaad) yang diatur di dalam Pasal 1365 Burgerlijk Wetboek (BW) dan gugatan wanprestasi yang diatur di dalam Pasal 1243 jo. 1244 BW. ${ }^{10}$

Di Indonesia, gugatan dengan objek tanah ini begitu tinggi, bahkan menempati peringkat pertama dalam jenis perkara perdata yang masuk di pengadilan negeri. Pada tahun 2018, jumlah perkara yang masuk ke pengadilan negeri ada sekitar 87.274 (delapan puluh tujuh ribu dua ratus tujuh puluh empat). ${ }^{11}$ Dari jumlah tersebut, 18.746 (delapan belas ribu tujuh ratus empat puluh enam). Berdasarkan jumlah tersebut, dapat dilihat bahwa $21.48 \%$ dari seluruh perkara perdata yang masuk ke pengadilan negeri adalah perkara dengan objek sengketa tanah. ${ }^{12}$

Ditempatinya peringkat pertama pada perkara perdata dengan objek sengketa tanah di pengadilan negeri, menunjukan bahwa banyak sekali penduduk Indonesia yang mempermasalahkan terkait dengan kepemilikan hak atas tanah. Ditempatinya peringkat pertama pada perkara perdata dengan objek sengketa tanah di pengadilan negeri ini, juga menunjukan, bahwa tanah itu begitu berharga bagi penduduk Indonesia, bahkan tidak segan membawa permasalahan terkait dengan sengketa terkait hak atas tanah ini sampai ke pengadilan. Tingginya sengketa tanah di Indonesia tidak lantas membuat hakim kemudian dapat memutus secara sembarangan terkait dengan sengketa yang berkaitan dengan tanah ini. Hakim tetap memiliki kewajiban untuk berhati-hati dan cermat dalam memutus perkara. Hal ini sesuai dengan pendapat Haskell M.Pitluck, bahwa: "Judges must be very careful as to the accuracy of all information on such statements. In this modern age of social networking, since judge are public figures in powerful position in demanding respect..."13

Salah satu bentuk kehati-hatian hakim dalam mengambil keputusan terhadap gugatan dengan objek sengketa tanah, maka hakim umumnya melakukan pemeriksaan setempat (descente/ gerechtelijke plaatsopneming / site visit investigation). Pemeriksaan setempat ini adalah pemeriksaan yang dilakukan secara langsung oleh hakim untuk

\footnotetext{
${ }^{9}$ Juan Maulana Alfedo, Emilda Yofita, Laras Ayu Lintang Sari, Conceptualizing the Floating Court Based On E-Floating Court to Realizing Public Service the Justice System in The Fourth Industrial Revolution Era, Vol. 4 No. 1 Edisi Mei 2020, https://journal.unnes.ac.id/sju/index.php/1slr/article/view/37732, diakses tgl 29 Mei 2020

${ }^{10}$ Sri Redjeki Slamet, Tuntutan Ganti Rugi dalam Perbuatan Melawan Hukum: suatu Perbandingan dengan Wanprestasi, Vol. 10 No. 2 Edisi Agustus 2013, https://www.neliti.com/publications/18068/tuntutan-ganti-rugi-dalam-perbuatan-melawan-hukum-suatu-perbandingan-dengan-wanp, diakses tgl 29 Mei 2020

${ }^{11}$ Tim Pokja Laporan Tahunan Mahkamah Agung Republik Indonesia, 2018, Laporan Tahunan 2018 Mahkamah Agung Republik Indonesia: Era Baru Peradilan Modern Berbasis Teknologi Informasi, Mahkamah Agung Republik Indonesia, Jakarta, hlm.110.

${ }^{12}$ Ibid.

${ }^{13}$ Haskell M.Pitluck, 2012, Judicial Ethics dalam J.C. Upshaw Downs Anjali Ranadive Swienton, Ethics in Forensic Science, Academic Press, hlm.384.
} 
melihat tanah yang menjadi objek sengketa. ${ }^{14} \mathrm{Hal}$ ini dilakukan oleh hakim dengan tujuan untuk melakukan klarifikasi terhadap tanah yang menjadi objek sengketa. Jangan sampai tanah yang menjadi objek sengketa ternyata bukanlah tanah dari para pihak atau tanah yang menjadi objek sengketa ternyata tidak ada secara nyata.

Dalam perkembangannya, berdasarkan Surat Edaran Mahkamah Agung Nomor 7 Tahun 2001 (SEMA 7/2001) Tentang Pemeriksaan Setempat, Mahkamah Agung meminta perhatian Ketua/majelis hakim yang memeriksa perkara perdata dengan objek sengketa tanah untuk melakukan pemeriksaan sempat. Dalam pertimbangan dikeluarkannya SEMA 7/2001 ini, dapat dilihat bahwa Mahkamah Agung mencoba memberikan guideline agar dilaksanakannya pemeriksaan setempat terhadap gugatan perdata dengan objek sengketa tanah. Adanya SEMA 7/2001 ini kemudian menjadi pedoman bagi hakim untuk melakukan pemeriksaan setempat dalam setiap perkara perdata yang objek sengketanya adalah tanah.

Dalam perkembangannya pemeriksaan setempat ini "seolah-olah" menjadi salah satu prosedur yang harus dilakukan dalam perkara dengan objek sengketa tanah. Apabila para pihak tidak mengajukan pemeriksaan setempat, maka hakim yang akan mengajukan pemeriksaan setempat dan umumnya biaya pemeriksaan setempat tersebut akan dibagi sama rata antara Penggugat dan Tergugat. Hal ini sejatinya menimbulkan problematika hukum, karena tidak selalu para pihak yang bersengketa mampu untuk membayar biaya pemeriksaan setempat, apalagi ketika objek sengketa tersebut adalah tanah yang luas, maka tentunya harga pemeriksaan setempat tersebut akan semakin mahal. Belum lagi, jika Tergugat tersebut yang notabene "tidak memiliki niat" untuk digugat ternyata harus mengeluarkan uang lebih atas hal yang tidak dikehendakinya (tidak menghendaki untuk menggugat).

Akan timbul pertanyaan ketika hakim meminta untuk melakukan pemeriksaan setempat, namun para pihak tidak menghendaki adanya pemeriksaan setempat maka konsekuensi hukum apa yang akan timbul? Untuk menjawab pertanyaan tersebut tentunya harus dipahami terlebih dahulu mengenai konsep, pengaturan, dan kedudukan pemeriksaan setempat dalam gugatan dengan objek sengketa tanah. Setelah memahami konsep, pengaturan, dan kedudukan pemeriksaan setempat dalam gugatan dengan objek sengketa tanah, barulah bisa menjawab akibat hukum dari tidak dilakukannya pemeriksaan setempat yang diminta oleh hakim tersebut. Berdasarkan latar belakang tersebut, maka rumusan masalah dalam penelitian ini adalah:

1. Bagaimana kedudukan pemeriksaan setempat (gerechtelijke plaatsopneming) di dalam peraturan perundangan di Indonesia?

2. Apa akibat hukum tidak dilakukannya pemeriksaan setempat (gerechtelijke plaatsopneming) terhadap gugatan dengan objek sengketa tanah?

Penelitian ini adalah penelitian hukum normatif. Penelitian hukum normatif atau normative legal research adalah penelitian hukum yang meletakkan hukum sebagai sebuah bangunan sistem norma yang meneliti asas-asas, norma, kaidah dari peraturan

\footnotetext{
${ }^{14}$ Ratih Mannul Izzati1 dan Nyoman Serikat Putra Jaya, Dampak Yuridis Pemeriksaan Setempat (Gerechtelijke Plaatsopneming) Dalam Hukum Acara Pidana Dipandang Dari Aspek Pertimbangan Hukum Putusan Perkara Pidana, Vol. 8 No. 1 Edisi Januari 2012, https://ejournal.undip.ac.id/index.php/lawreform/article/view/12416, diakses tgl 29 Mei 2020.
} 
perundangan, putusan pengadilan, perjanjian, serta doktrin (ajaran). ${ }^{15}$ Dalam penulisan pendekatan yang digunakan adalah statute approach (pendekatan perundang-undangan), conceptual approach (pendekatan konseptual) dan case approach (pendekatan kasus). statute approach (pendekatan perundang-undangan) dilakukan dengan menelaah semua Undang-Undang dan regulasi yang bersangkut paut dengan isu hukum yang sedang ditangani. ${ }^{16}$. Conceptual approach (pendekatan konseptual) adalah pendekatan yang menggunakan pandangan-pandangan dan doktrin-doktrin yang ada di dalam ilmu hukum untuk menganalisa isu hukum yang ada. ${ }^{17}$ Case approach (pendekatan kasus) digunakan dengan cara melakukan telaah terhadap kasus-kasus yang berkaitan dengan isu yang dihadapi yang telah menjadi putusan pengadilan yang telah mempunyai kekuatan hukum yang tetap. ${ }^{18}$

Pendekatan perundang-undangan dilakukan dengan menganalisa berbagai peraturan perundang-undangan yang terkait pemeriksaan setempat dalam gugatan dengan objek sengketa tanah. Untuk mendukung penelitian ini agar lebih komprehensif, maka pendekatan konsep dilakukan dengan mempelajari berbagai pandangan, doktrin, konsep, dan asas-asas hukum agar dapat membangun suatu argumentasi hukum dalam memecahkan isu yang dihadapi berkaitan dengan pemeriksaan setempat dalam gugatan dengan objek sengketa tanah. Cum adsunt testimonia rerum, quid opus est verbist, sebuah adagium hukum yang berarti, saat bukti dan fakta sudah ada, apalah guna kata-kata. Dalam hal ini, untuk membuktikan argumentasi dalam penelitian ini, maka akan ditambahkan kajian terkait putusan-putusan yang memiliki relevansi dengan pemeriksaan setempat dalam gugatan dengan objek sengketa tanah, sehingga tercipta penelitian hukum yang holistik.

\section{PEMBAHASAN}

\section{Kedudukan Pemeriksaan Setempat (gerechtelijke plaatsopneming) di dalam Per- aturan Perundang-Undangan di Indonesia}

Ad recte docendum oportet primum inquirre nomina, quia rerum cognition a nominibus rerum dependet. ${ }^{19}$ Sebuah postulat hukum klasik yang terjemahannya berarti, agar dapat memahami sesuatu, perlu diketahui terlebih dahulu namanya agar mendapat pengetahuan yang benar. ${ }^{20}$ Postulat tersebut, sejatinya memiliki kedalaman makna, bahwa untuk memahami sesuatu secara holistik, maka harus diawali dengan memahami definisinya terlebih dahulu. Dalam kaitan dengan memahami kedudukan pemeriksaan setempat dalam peraturan perundang-undangan di Indonesia, maka harus diawali dengan memahami terlebih dahulu definisi dari pemeriksaan setempat tersebut.

"Over de Indonesische taal spreken is onzin, maar spreken over de Indonesische wet is heel logisch" (Berbicara tentang bahasa Indonesia adalah omong kosong, tetapi berbicara

\footnotetext{
${ }^{15}$ Mukti Fajar dan Yulianto Achmad, 2010, Dualisme Penelitian Hukum Normatif dan Empiris, Cetakan IV, Pustaka Pelajar, Yogyakarta, hlm.33.

${ }^{16}$ Peter Mahmud Marzuki, 2010, Pengantar Ilmu Hukum, Cet. Ke-4, Prenada Media, Surabaya, hlm.133

${ }^{17}$ Salom HS. Dan Erlies Septiana Op.cit., hlm.19.

${ }^{18}$ Ibid.

${ }^{19}$ Xavier Nugraha, John Eno Prasito Putra, Krisna Darari Hamonangan Putra, Analisa Daluarsa Gugatan Pembatalan Perjanjian Akibat Adanya Penyalahgunaan Keadaan (Misbruik Van Omstandigheiden)). Galuh Justisi, vol.8 no. 1 edisi Maret 2020, hlm. 66.

${ }^{20}$ Eddy O.S. Hiariej, 2015, Prinsip-Prinsip Hukum Pidana Edisi Revisi,Cahaya Atma Pustaka, Yogyakarta, hlm. 3.
} 
tentang hukum Indonesia cukup masuk akal). ${ }^{21}$ Sebuah ungkapan yang disampaikan oleh Joost van Vollenhoven ketika datang ke Indonesia untuk mempelajari hukum yang ada sekitar 200 tahun lalu. ${ }^{22}$ Ungkapan tersebut, sejatinya justru terbukti terbalik. Sejak tahun 1988, Indonesia telah berhasil membuat Kamus Besar Bahasa Indonesia (KBBI) pertama yang notabene berisi pedoman terkait Bahasa Indonesian namun hingga kini banyak aturan hukum yang belum mampu dibentuk oleh Indonesia sendiri. ${ }^{23} \mathrm{Hal}$ ini menyebabkan, masih banyak aturan di Indonesia yang masih menggunakan bekas peninggalan Belanda dengan dasar asas konkordansi yang diatur dalam Pasal II aturan peralihan Undang-Undang Dasar 1945 dan Peraturan Pemerintah Nomor 2 Tahun 1945. ${ }^{24}$ Salah satu aturan yang masih menggunakan bekas peninggalan Belanda adalah terkait dengan hukum acara perdata yang notabene umumnya masih menggunakan Herzien Indonesis Reglement (HIR) atau Rechtsreglement Buitengewesten (RBg). ${ }^{25}$

Dengan masih digunakannya HIR dan RBg sebagai dasar hukum acara perdata di Indonesia, maka masih banyak hal-hal yang tidak diatur secara spesifik. Hal ini logis, mengingat aturan tersebut dibentuk puluhan tahun yang lalu, sehingga bisa dikatakan belum banyak hal yang diatur secara spesifik. Salah satu hal yang belum diatur dengan spesifik ini adalah pemeriksaan setempat tersebut. Tidak ada satu aturan pun (bahkan SEMA) yang memberikan definisi secara konkrit mengenai konsep pemeriksaan setempat.

Dalam perkembangannya, untuk mengisi kekosongan hukum terkait definisi pemeriksaan setempat, maka digunakan pendapat ahli hukum yang notabene bisa sebagai sumber hukum (doktrin). ${ }^{26}$ Berikut adalah beberapa pendapat ahli terkait definisi pemeriksaan setempat:

1. MenurutSudikno Mertokusumo, pemeriksaan setempatadalahpemeriksaanmengenai perkaraolehHakimkarenajabatannyayangdilakukandiluargedung tempatkedudukan pengadilan, agar Hakim dengan melihat sendirimemperoleh gambaran atau keterangan yang memberi kepastian tentang peristiwa-peristiwa yang menjadi sengketa. ${ }^{27}$

2. Menurut Yahya Harahap, pemeriksaan setempat berarti sidang pengadilan yang dilakukan di tempat objek barang terperkara terletak, untuk melihat keadaan atau pemeriksaan secara langsung objek tersebut. ${ }^{28}$

3. Menurut Roihan A. Rasyid, bahwa pemeriksaan setempat adalah sidang pengadilan yang dipindahkan ke suatu tempat tertentu, yang lengkap berita acara sidangnya seperti biasa dan masih termasuk wilayah pengadilan tersebut. ${ }^{29}$

\footnotetext{
${ }^{21}$ J. Burns, 2004 The Leiden Legacy: Concepts of Law in Indonesia, Pradnya Paramita, Jakarta, hlm.52.

22 Shidarta, 2013, Hukum Penalaran dan Penalaran Hukum Akar Filosofis, Genta Publishing, Yogyakarta, hlm.225.

${ }^{23}$ Tribunnews, Mengenal Lebih Jauh KBBI, Dari Sejarah Sampai Proses Masuknya Sebuah Kata, https://www. tribunnews.com/pendidikan/2019/12/06/mengenal-lebih-jauh-kbbi-dari-sejarah-sampai-proses-masuknya-sebuah-kata?page $=3$, diakses pada tanggal 1 Juni 2020 .

${ }^{24}$ Ery Agus Priyono, Pengaruh Globalisasi Ekonomi Terhadap Perubahan Peraturan Bidang Perjanjian di Indonesia. Diponegoro Law Review, vol.3 no.1, edisi Juni 2018, hlm.248-260.

${ }^{25}$ HIR berlaku untuk Jawa dan Madura, sementara RBg Untuk Daerah (berlaku untuk daerah luar Jawa dan Madura).

${ }^{26}$ Sumber hukum dalam arti formil adalah Peraturan perundang-undangan, kebiasaan, doktrin, traktat, yurisprudensi. Selebihnya lihat Theresia Ngutra, Hukum dan Sumber-Sumber Hukum, Jurnal Supremasi, vol.11 no.2, edisi Juni 2016, hlm.193-209.

${ }^{27}$ Sudikno Mertokusumo, 2006, Hukum Acara Perdata Indonesia, Liberty, Yogyakarta, hlm.197.

${ }^{28}$ M. Yahya Harahap, 2016, Hukum Acara Perdata, Sinar Grafika, Jakarta, hlm.781.

${ }^{29}$ Roihan A. Rasyid, 2016, Hukum Acara Peradilan Agama, Rajawali Pers, Jakarta, hlm. 198.
} 
Jika menarik sintesis dari berbagai pendapat terkait pemeriksaan setempat tersebut, dapat dilihat bahwa pemeriksaan setempat adalah pemeriksaan perkara antara para pihak dan hakim, serta dilaksanakan di luar gedung Pengadilan, di tempat objek sengketa itu berada.

Adapun tujuan dari dilaksanakannya pemeriksaan setempat adalah:

1. Mengetahui dengan jelas dan pasti terkait dengan objek sengketa, seperti lokasi, luas dan batas- batas objek (tanah) yang menjadi objek sengketa.

2. Untuk memastikan bahwa antara bukti yang ada di persidangan (sertifikat, saksi, dan sebagainya) dengan objek sengketa secara riil adalah sama.

3. Agar objek sengketa tersebut benar-benar dapat dieksekusi secara nyata (executable).

4. Agar jangan sampai objek sengketa yang dieksekusi ternyata adalah milik orang lain, sehingga merugikan pihak lain.

Berikut diagram alir proses pelaksanaan pemeriksaan setempat:

Gambar 1. Alur Pemeriksaan Setempat

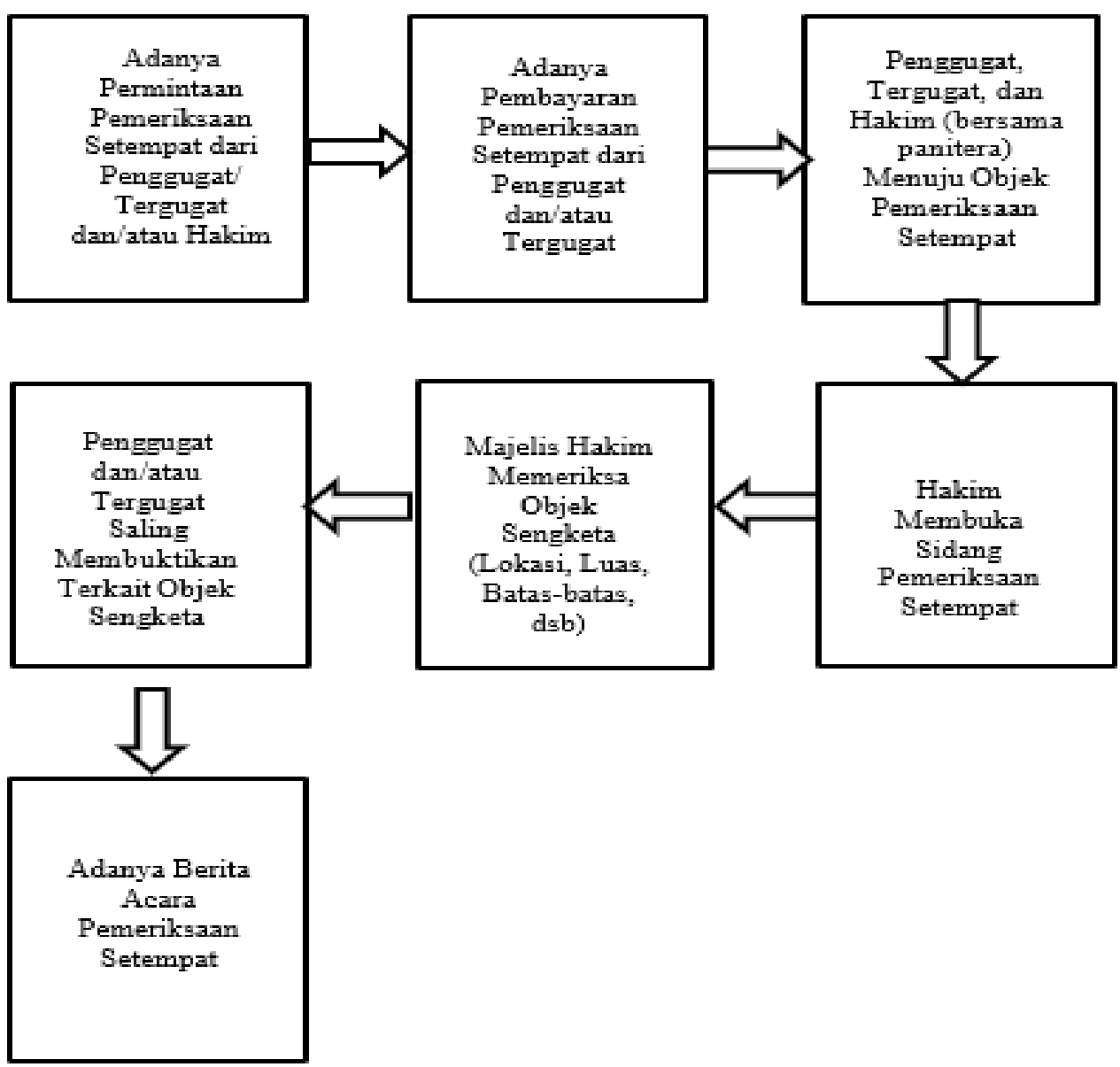

Sumber: Data yang diolah sendiri

Terkait dasar hukum dilaksanakannya pengaturan pemeriksaan setempat di peraturan perundang-undangan di Indonesia antara lain adalah:

a) HIR

Di HIR, Pemeriksaan setempat ini diatur dalam Pasal 153 yang mengatur bahwa: 
(1) Jika dipandang perlu atau berfaedah, ketua boleh mengangkat satu atau dua komisaris dari dewan itu, yang dengan bantuan panitera pengadilan akan melihat tempat atau merupakan pemeriksaan di tempat itu, yang dapat menjadi keterangan bagi hakim (penebalan dari penulis).

(2) Panitera pengadilan hendaklah membuat berita acara tentang pekerjaan itu dan hasilnya;beritaacaraituharusditandatanganiolehkomisarisdanpaniterapengadilan itu.

b) Rbg

Di Rbg, Pemeriksaan setempat ini diatur dalam Pasal 180 yang mengatur bahwa:

(1) Ketua, jika dipandangnya perlu atau bermanfaat, dapat mengangkat satu atau dua orang komisaris untuk, dengan dibantu oleh panitera, mengadakan pemeriksaan di tempat agar mendapat tambahan keterangan (penebalan dari penulis).

(2) Tentang apa yang dilakukan oleh komisaris serta pendapatnya dibuat berita acara atau pemberitaan oleh panitera dan ditandatangani oleh komisaris dan panitera itu (HIR. 153.)

(3) jika tempat yang akan diperiksa terletak di luar wilayah jaksa tempat kedudukan pengadilan negeri, maka ketua dapat meminta jaksa di tempat tersebut mengadakan atau menyuruh mengadakan pemeriksaan dan secepatnya mengirimkan berita acara tentang pemeriksaan tersebut kepada ketua.

c) SEMA $7 / 2001$

Dalam SEMA 7/2001, disebutkan bahwa Mahkamah Agung meminta perhatian Ketua/majelis Hakim yang memeriksa Perkara perdata untuk:

a. Mengadakan Pemeriksaan Setempat atas objek perkara yang perlu dilakukan oleh Majelis Hakim dengan dibantu oleh Panitera Pengganti baik atas inisiatif Hakim karena merasa perlu mendapatkan penjelasan/keterangan yang lebih rinci atas obyek perkara maupun karena diajukan eksepsi atau atas permintaan salah satu pihak yang berperkara (penebalan dari penulis).

b. Apabila dipandang perlu dan atas persetujuan para pihak yang berperkara dapat pula dilakukan Pengukuran dan Pembuatan Gambar Situasi Tanah/Obyek Perkara yang dilakukan oleh Kantor Badan Pertanahan Nasional Setempat dengan biaya yang disepakati oleh kedua belah pihak, apakah akan ditanggung oleh Penggugat atau dibiayai bersama dengan Tergugat.

c. Dalam melakukan Pemeriksaan Setempat agar diperhatikan ketentuan Pasal 150 HIR/180RBg.,danPetunjukMahkamahAgungTentangBiayaPemeriksaanSetempat (SEMA Nomor: 5 Tahun 1999 Point 8) dan Pembuatan Berita Acara Pemeriksaan Setempat.

Dalam membaca suatu teks peraturan perundang-undangan, terdapat adagium hukum yang sangat mendasar, yaitu primo executienda est verbis vis, ne sermonis vitio obstruatur oratio, sive lex sine argumentis, yang berarti perkataan adalah hal yang pertama diperiksa untuk mencegah adanya kesalahan pengertian atau kekeliruan dalam menemukan hukum. Adagium hukum tersebut memiliki kedalaman makna, bahwa dalam menemukan hukum, harus dilihat terlebih dulu di dalam peraturan perundangundangan. Ketika telah diatur dalam peraturan perundang-undangan, maka tertutup 
ruang untuk melakukan penemuan lebih lanjut. Hal ini juga sesuai dengan adagium interpretatio cessat in claris yang berarti apa yang sudah jelas-jelas diatur di dalam peraturan perundang-undangan tidak diperkenankan lagi untuk ditafsirkan. Berkaitan dengan pengaturan pemeriksaan setempat di dalam berbagai regulasi tersebut, dapat dilihat secara experis verbis, bahwa pemeriksaan setempat ini sifatnya hanyalah opsional/ tidak wajib.

Jika melihat secara gramatikal, frasa yang dipilih untuk digunakan, baik di dalam HIR, Rbg, dan SEMA7/2001 hanya bersifat opsional. Hal ini dapat dilihat dari pilihan frasa yang digunakan, yaitu "jika dirasa perlu". Tidak ada frasa yang sifatnya imperatif, seperti adanya frasa "wajib". Hal ini berarti, konsekuensi yuridisnya adalah pemeriksaan setempat bukanlah satu proses yang wajib dilakukan di dalam gugatan yang objeknya adalah tanah atau benda tidak bergerak lainnya.

Jika dilihat di dalam HIR, Rbg, dan SEMA, pemeriksaan setempat sejatinya memang tidak bersifat wajib dalam satu proses gugatan dengan objek sengketa perdata, namun hal yang harus diperhatikan adalah terkait dengan "ketika dirasakan perlu" ini. Jika melihat di dalam HIR, Rbg, dan SEMA, sejatinya terdapat delapan posibilitas, terkait pihak yang merasakan diperlukannya pemeriksaan setempat yaitu:

Tabel 1. Probabilitas Para Pihak yang Merasa Perlu Mengajukan Pemeriksaan Setempat

\begin{tabular}{|cccc|} 
Nomor & Hakim & Tergugat & Penggugat \\
$\mathbf{1}$ & $\mathrm{V}$ & $\mathrm{V}$ & $\mathrm{V}$ \\
$\mathbf{2}$ & $\mathrm{V}$ & $\mathrm{V}$ & $\mathrm{X}$ \\
$\mathbf{3}$ & $\mathrm{V}$ & $\mathrm{X}$ & $\mathrm{V}$ \\
$\mathbf{4}$ & $\mathrm{V}$ & $\mathrm{X}$ & $\mathrm{X}$ \\
$\mathbf{5}$ & $\mathrm{X}$ & $\mathrm{V}$ & $\mathrm{X}$ \\
$\mathbf{6}$ & $\mathrm{X}$ & $\mathrm{X}$ & $\mathrm{V}$ \\
$\mathbf{7}$ & $\mathrm{X}$ & $\mathrm{V}$ & $\mathrm{V}$ \\
$\mathbf{8}$ & $\mathrm{X}$ & $\mathrm{X}$ & $\mathrm{X}$ \\
\hline
\end{tabular}

Keterangan:

$\mathrm{V}=$ Merasa Perlu

$\mathrm{X}=$ Merasa Tidak Perlu

Sumber: Data yang diolah sendiri

Dari delapan posibilitas tersebut, memang terdapat kemungkinan di mana salah satu pihak (Hakim, Tergugat, Penggugat), merasa tidak perlu untuk melakukan pemeriksaan setempat, namun apabila terdapat salah satu pihak yang merasa diperlukan adanya pemeriksaan setempat, maka seyogyanya pihak lain tidak diperkenankan untuk 
menolak. Argumentasi ini didasarkan pada interpretasi gramatikal, di dalam SEMA 7/2001 yang mengatur, bahwa:

"Mengadakan Pemeriksaan Setempat atas objek perkara yang perlu dilakukan oleh Majelis Hakim dengan dibantu oleh Panitera Pengganti baik atas inisiatif Hakim karena merasa perlu mendapatkan penjelasan/keterangan yang lebih rinci atas obyek perkara maupun karena diajukan eksepsi atau atas permintaan salah satu pihak yang berperkara (penebalan dari penulis).

Dari SEMA 7/2001 tersebut, dapat dilihat, bahwa cukup dengan inisiatif dari salah satu pihak (Hakim, Tergugat, Penggugat), maka pemeriksaan setempat dapat dilakukan. Menurut Penulis, bahkan ketika salah satu pihak telah menghendaki adanya pemeriksaan setempat, maka sejatinya pemeriksaan setempat ini bersifat wajib. Dengan dasar tersebut, maka pihak lain yang tidak merasa perlu melakukan pemeriksaan setempat, tidak dapat menolak untuk melakukan pemeriksaan setempat.

\section{Akibat Hukum Tidak Adanya Pemeriksaan Setempat (Gerechtelijke Plaatsopne- ming) Terhadap Gugatan dengan Objek Sengketa Tanah}

Dari delapan posibilitas tersebut, apabila Penggugat dan/atau Tergugat merasa perlu dilakukannya pemeriksaan setempat, maka hal ini tidak menimbulkan problematika hukum. Jika Penggugat dan/atau Tergugat merasa diperlukan pemeriksaan setempat, Penggugat dan/atau Tergugat yang akan melakukan pembayaran, sementara ketika Penggugat dan/atau Tergugat tidak merasa diperlukan pemeriksaan setempat, sementara hakim merasa memerlukan pemeriksaan setempat, problematika mendasar yang muncul adalah terkait pihak yang akan menanggung biaya pemeriksaan setempat. Jika melihat pada ketentuan di dalam Pasal 214 Wetboek op de Burgerlijke Rechtvordering (Rv) terkait pemeriksaan setempat, disebutkan bahwa: "Ongkos jalan ditanggung oleh pihak yang menghendaki diadakannya Pengamatan atau penyaksian setempat, dibayar lebih dan diserahkan kepada panitera. Jika hakim yang memerintahkan pengamatan dan penyaksian setempat, maka ia menentukan pula siapa yang harus membayar lebih dulu biayanya." Berdasarkan ketentuan tersebut, dapat dimaknai, bahwa yang membayar pemeriksaan setempat adalah:

1. Pihak yang meminta pemeriksaan setempat (Penggugat Dan/Atau Tergugat)

2. Apabila pemeriksaan setempat atas dasar hakim secara ex officio maka beban pembayarannya ditentukan oleh hakim sendiri.

Berdasarkan ketentuan Pasal 214 Rv tersebut, dapat dilihat bahwa ketika pemeriksaan setempat dilakukan karena dirasa perlu oleh hakim, maka beban pembayaran akan ditentukan oleh hakim. Adapun Indikator pembiayaan di dalam pelaksana pemeriksaan setempat terdiri dari: ${ }^{30}$

1. Biaya kantor panitra dan biaya materai

2. Biaya saksi, ahli, atau juru bahasa

3. Biaya pemeriksaan setempat

4. Biaya pemanggilan

5. Biaya yang disebut dalam pasal 138 HIR.

${ }^{30}$ Hasan Ismail Efendi Nst, 2018, Pemeriksaan Setempat Sebagai Bahan Pertimbangan Hakim Memutus Sengketa Tanah (Analisis Putusan Nomor 345/Pdt/2015/Pt-Mdn), Skripsi, Fakultas Hukum Universitas Muhammadiyah Malang, hlm.18. 
6. Biaya eksekusi

Dalam hal mempertimbangkan pihak yang akan dibebani beban pembiayaan, maka berikut urutan pihak yang seyogyanya akan dibebani biaya oleh hakim:

1. Penggugat

Hal ini didasarkan pada dua argumentasi, yaitu:

- Penggugat memiliki beban utama sebagai pihak yang mendalilkan adanya asasasas mendasar dalam hukum pembuktian, yaitu: ${ }^{31}$

a) actori in cumbit probatio ei incumbit, yang berarti pihak yang mempunyai hak atau mendalilkan suatu kejadian, maka harus membuktikan adanya hak atau peristiwa tersebut

b) probatio quidicit, non qui negat yang memiliki arti beban pembuktian ada pada orang yang menggugat, bukan yang Tergugat.

c) probandinecessitas incumbit illiqui agit yang berarti beban pembuktian dilimpahkan kepada Penggugat,

d) semper necessitas probandi incumbit ei qui agit yang berarti beban pembuktian selalu dilimpahkan pada Penggugat.

e) affirmanti, non neganti, incumbit probation yang berarti pembuktian bersifat wajib bagi yang mengajukan bukan yang menyangkal

f) affirmantisest probareberarti orang yang mengakseptasi, maka harus membuktikan.

g) reonegate actori incumbit probatio yang berartijika Tergugat tidak mengakui gugatan, maka Penggugat harus membuktikan.

Intisari dari asas-asas tersebut adalah pihak yang menggugat memilikibeban utama untuk membuktikan. Hal ini diatur di dalam Pasal 163 HIR jo. Pasal 1865 BW. Dengan demikian, ketika hakim merasa perlu adanya pemeriksaan setempat, hal ini untuk memperjelas gugatan dari Penggugat. Dengan demikian, Penggugat sebagai pihak yang notabene memiliki beban utama untuk mendalilkan dalam suatu gugatan seyogyanya yang menanggung beban biaya pemeriksaan setempat tersebut.

\section{- Adanya Gugatan Diinisiasi oleh Penggugat}

Jika melihat dalam proses gugatan secara holistik, maka dapat dilihat bahwa awal mula adanya gugatan dikehendaki atau diinisiasi oleh Penggugat. Penggugat notabene merupakan pihak yang paling memiliki kepentingan, sehingga mengajukan gugatan. Tanpa adanya keinginan Penggugat untuk mengajukan gugatan, maka tidak mungkin adanya gugatan tersebut. Dengan dasar tersebut, maka logis beban biaya pemeriksaan setempat ditangguhkan kepada Penggugat.

2. Tergugat

MenurutAristoteleskeadilanitutidaklahsama.Aristoteles menyebutkan:" "Equals should be treated equally and unequals unequally." Menurut Aristoteles, keadilan berarti memperlakukan setiap individu secara sama, kecuali mereka berbeda dalam cara yang relevan dengan situasi di mana mereka terlibat. Dalam konteks pembebanan biaya dalam pemeriksaan setempat oleh hakim, apabila pihak Penggugat berada pada posisi

\footnotetext{
${ }^{31}$ Risalah Sidang Perkara Mahkamah Konstitusi Nomor 01/PHPU-PRES/XVII/2019, hlm.202.

${ }^{32}$ Raj Kumar Gupta, Justice: Unequal but Inseparate, Vol. 11 No. 1, Edisi Januari 1969, https://www. jistor.org/stable/43950010?read-now $=1 \&$ seq $=8$ \#page scan tab contents, diakses pada tanggal 1 Juni 2020.
} 
yang lemah, maka hakim tidak boleh menutup mata pada realitas sosial tersebut.

Dalam kondisi Penggugat memiliki ekonomi yang lemah, maka dengan dasar keadilan dan kepatutan, maka hakim seyogyanya mempertimbangkan untuk membebankanbiayapemeriksaan setempatkepadaTergugat, meskipunPenggugat adalah pihak yang paling berkepentingan dalam suatu perkara.

Sebenarnya, tidak menutup kemungkinan, bahwa baik pihak Penggugat dan Tergugat, sama-sama pada posisi ekonomi yang lemah. Dalam hal demikian, sebenarnya jika mendasarkan pada argumen di atas, maka kembali pada argumen pertama, yaitu membebankan pada pihak Penggugat, karena notabene kedua belah pihak samasama berada pada posisi yang sama, yaitu sama-sama berada pada posisi ekonomi yang lemah. Dalam hal demikian, sebenarnya hakim memang dapat membebankan kepada Penggugat, namun hakim harus mempertimbangkan beberapa hal lagi, sebelum melaksanakan pemeriksaan setempat, apabila Penggugat dan Tergugat ada dalam posisi yang lemah. Adapun hal-hal yang seyogyanya dipertimbangkan lagi oleh hakim sebelum melaksanakan pemeriksaan setempat, apabila Penggugat dan Tergugat ada dalam posisi yang lemah, yaitu:

1. Para Pihak Saling Mengakui Tanah yang Menjadi Objek Sengketa

2. Para Pihak Memiliki Dokumen yang Menunjang Tanah yang Menjadi Objek Sengketa

Hakim seyogyanya, mempertimbangkan dua hal tersebut sebelum melakukan pemeriksaan setempat, apabila Penggugat dan Tergugat ada dalam posisi yang lemah. Hal ini didasarkan, agar pemeriksaan setempat tersebut memang benar-benar diperlukan. Apabila dua syarat itu telah terpenuhi secara kumulatif, maka dalam hal Penggugat dan Tergugat ada dalam posisi yang lemah, maka hakim seyogyanya perlu mempertimbangkan untuk tidak melakukan pemeriksaan setempat, namun bila dua hal tersebut tidak terpenuhi, maka meskipun Penggugat dan Tergugat ada dalam posisi yang lemah, pemeriksaan setempat seyogyanya tetap harus dilakukan.

Tidak menutup kemungkinan, bahwa dalam pelaksanaan pemeriksaan setempat yang dilakukan atas dasar inisiatif hakim semata, tanpa adanya keinginan dari pihak Penggugat dan Tergugat ini, pihak yang dibebani biaya oleh hakim tidak ingin melakukan pembayaran tersebut. Dalam hal tersebut, maka pemeriksaan setempat tersebut tidak akan dapat dilaksanakan. Hal ini sesuai dengan Pasal 160 HIR jo. Pasal 182 HIR. Di dalam peraturan perundang-undangan, memang tidak terdapat akibat hukum yang diatur secara experis verbis, jika tidak dilaksanakannya pemeriksaan setempat atas kehendak hakim.

Secara teoritis, tentunya akan terasa sangat aneh, ketika pemeriksaan setempat yang dikehendaki oleh salah satu pihak (dalam hal ini hakim), seperti diuraikan di atas merupakan suatu kewajiban, namun tidak terdapat konsekuensi yuridis ketika tidak dilaksanakan. Hal ini, akan menyebabkan norma yang seharusnya merupakan suatu kewajiban, berubah seolah-olah hanya menjadi anjuran semata. Norma kewajiban yang tidak memiliki konsekuensi hukum, ketika tidak dilaksanakan ini, secara teoritis disebut sebagai norma yang tidak sempurna (lex imperfecta). 
Id perfectum est quod ex omnibus suis partibus constat, sebuah postulat yang memiliki kedalaman makna bahwa sesuatu tidak akan sempurna kecuali tiap bagiannya komplit. ${ }^{33}$ Dalam hal untuk menyempurnakan norma tersebut, agar dapat disebut sebagai norma kewajiban yang sempurna, maka harus adanya konsekuensi hukum dalam norma kewajiban ini. Dalam rangka tidak dibayarnya biaya pemeriksaan setempat, sehingga tidak dapat dilaksanakannya pemeriksaan setempat yang dirasa perlu oleh hakim, maka akibat hukum yang ada, yaitu hakim dapat memutus, bahwa gugatan tersebut tidak dapat diterima (niet ontvankelijke verklaard).

Menurut M.Yahya Harahap, gugatan tidak dapat diterima dengan alasan-alasan, yaitu: ${ }^{34}$

1. Gugatan tidak memiliki dasar hukum;

2. Gugatan ne bis in idem;

3. Gugatan error in persona dalam bentuk diskualifikasi atau plurium litis consortium;

4. Gugatan mengandung cacat atau obscuur libel; atau

5. Gugatan melanggar yurisdiksi (kompetensi) absolut atau relatif,dsb.

Dalam kaitannya dengan tidak dibayarkannya biaya pemeriksaan setempat, sehingga tidak dapat dilaksanakannya pemeriksaan setempat yang dirasakan perlu oleh hakim, ini termasuk dengan alasan gugatan yang obscuur libel. Hakim dapat mendalilkan, bahwa hakim memerlukan pemeriksaan setempat dalam objek sengketa berupa tanah tersebut, sehingga tanpa adanya pemeriksaan setempat, maka terkait tanah yang menjadi objek sengketa tersebut menjadi tidak jelas. Hal ini sejatinya, juga dapat dilihat dalam beberapa ratio decedendi di dalam putusan, seperti:

1. Putusan Mahkamah Agung Nomor 1149 k/sip/1979 tanggal 17 April 1979, yang menyatakan, bahwa: "Bila tidak jelas batas-batas tanah sengketa, maka gugatan tidak dapat diterima".

2. Yurisprudensi Mahkamah Agung Nomor1149/K/Sip/1975 tanggal 17 April 1975 jo. PutusanMahkamahAgungNomor565/K/Sip/1973tanggal21Agustus1973,jo.Putusan Mahkamah Agung Nomor 1149/K/Sip/1979 tanggal 7 April 1979 yang menyatakan, bahwa: "terhadap objek gugatan yang tidak jelas, menyebabkan gugatan tersebut tidak dapat diterima." 35

3. Putusan Mahkamah Agung Nomor 40 PK/Pdt/2014, yang menyatakan, bahwa: "Selain tidak diketahui dengan pasti keadaan fisik dan batas-batas objek sengketa, karena Judex Facti/Pengadilan Negeri Jakarta Timur tidak melakukan Pemeriksaan Setempat (plaatsopname).Danolehkarena tidak melakukan Pemeriksaan Setempat pula putusan Judex Facti/PN Jakarta Timur yang dikuatkan oleh Judex Facti/Pengadilan Tinggi dan Judex Juris yang membenarkan demikian saja dalil Para Penggugat, bahwa tanah objek sengketa sampai dengan sekarang dikuasai oleh Para Penggugat/Para Termohon Kasasi, bukanlah fakta di lapangan." ${ }^{36}$

\footnotetext{
${ }^{33}$ Jihan Anjania Aldi, Elma Putri Tanbun, Xavier Nugraha, Tinjauan Yuridis Kewenangan Dewan Kehormatan Penyelenggara Pemilu (DKPP) Dalam Menciptakan Pemilu Yang Demokratis Di Indonesia. Jurnal Hukum De' Rechthstaat, vol.5 no.2 edisi Juni 2019, hlm. 139.

${ }^{34}$ M. Yahya Harahap Op.cit., hlm.811.

${ }^{35}$ Diana Kusumasari, Arti Gugatan Dikabulkan, Ditolak, dan Tidak Dapat Diterima, https https://www.hukumonline.com/klinik/detail/ulasan/c13157/putusan-hakim-dalam-acara-perdata/ diakses pada tanggal 1 Juni 2020.

${ }_{36}$ Herry Shietra, Pemeriksaan Setempat oleh Hakim dalam Pemeriksaan Sengketa Tanah, https https:// www.hukum-hukum.com/2017/10/pemeriksaan-setempat-oleh-hakim-sengketa-tanah.html $\frac{\text { diakses }}{\text { diand }}$
} 
Adanya akibat hukum berupa gugatan tersebut tidak dapat diterima dalam hal tidak dapat dilaksanakannya pemeriksaan setempat yang dirasakan perlu oleh hakim ini, seolah-olah hanya merugikan Penggugat dan menguntungkan Tergugat. Padahal, seperti uraian di atas, terdapat probabilitas ketika Tergugat yang akan dibebankan oleh hakim untuk membayarkan biaya perkara pemeriksaan setempat. Misal, dalam keadaan, ketika Penggugat dalam keadaan ekonomi lemah, yang notabene hakim seyogyanya membebankan kepada Tergugat. Memang, secara riil kerugian akan lebih besar ada pada Penggugat, ketika gugatan tersebut dinyatakan oleh hakim tidak dapat diterima, sehingga mungkin saja Tergugat menyadari hal ini, sehingga memanfaatkan celah hukum ini, untuk tidak membayar biaya pemeriksaan setempat yang diperintahkan oleh hakim. Dalam hal demikian, Penggugat yang dalam keadaan ekonomi lemah tersebut, dapat mengajukan agar dia yang membayarkan biaya pemeriksaan setempat tersebut, untuk menghindari gugatannya tidak dapat diterima.

Seolah-olah, dalam hal tersebut Tergugat memiliki celah hukum, padahal terdapat beberapa kerugian yang akan dialami Tergugat, ketika gugatan dengan objek sengketa berupa tanah tersebut tidak dapat diterima, yaitu:

1. Dimungkinkan adanya pengajuan gugatan dengan objek serupa

2. Akan menghabiskan banyak waktu untuk menghadapi gugatan dengan objek serupa

3. Tidak ada kepastian hukum terkait dengan hak milik terhadap tanah yang menjadi objek sengketa

4. Adanya blokir terhadap tanah yang menjadi objek sengketa, sehingga tidak bisa dilakukannya perpindahan hak

Dengan adanya kelemahan-kelemah ini, sejatinya ketika gugatan tersebut terusmenerus tidak dapat diterima, sejatinya juga memberikan kelemahan kepada tergugat. Tergugat, seolah-olah harus menghadapi potensi gugatan yang ad infinitum dari Penggugat. Justru ketika Tergugat, merasa, bahwa tanah yang menjadi objek sengketa tersebut adalah benar-benar didapatkan dengan itikad baik (bonum fide) dan sesuai dengan hukum yang berlaku, maka Tergugat tidak perlu takut untuk membayar biaya pemeriksaan setempat, sehingga hakim dapat masuk ke pokok perkara, untuk memutuskan hak atas tanah yang menjadi objek sengketa tersebut.

\section{SIMPULAN}

Di dalam peraturan perundang-undangan di Indonesia, terkait dengan kedudukan pemeriksaan setempat dalam gugatan dengan objek sengketa berupa tanah masih belum mendapat kedudukan hukum yang jelas. Jika melihat secara gramatikal, frasa yang ada di dalam peraturan perundang-undangan di Indonesia adalah, "jika dirasa perlu". Tidak ada frasa yang sifatnya imperatif, seperti adanya frasa "wajib". Hal ini berarti, pemeriksaan setempat bukanlah satu proses yang wajib dilakukan di dalam gugatan yang objeknya adalah tanah atau benda tidak bergerak lainnya. Akan tetapi, konsekuensi yuridis, dari digunakannya frasa "jika dirasa perlu" adalah, ketika salah satu pihak (Penggugat, Tergugat, atau Hakim) telah menghendaki adanya pemeriksaan setempat, maka sejatinya pemeriksaan setempat ini bersifat wajib.

pada tanggal 1 Juni 2020. 
Dalam hal pelaksana pemeriksaan setempat tersebut, kondisi yang paling mungkin untuk tidak dilakukannya pemeriksaan setempat adalah pemeriksaan setempat yang hanya dirasa perlu oleh hakim, namun tidak dirasa perlu oleh Penggugat dan Tergugat. Dalam kondisi demikian, maka akibat hukum yang mungkin timbul adalah gugatan tersebut tidak dapat diterima (niet ontvankelijke verklaard. Gugatan tersebut tidak dapat diterima, karena gugatan tersebut kabur (obscuur libel).

\section{DAFTAR PUSTAKA}

\section{Buku}

Burns, J., (2004), The Leiden Legacy: Concepts of Law in Indonesia, Pradnya Paramita, Jakarta.

Fajar, Mukti dan Yulianto Achmad, (2010), Dualisme Penelitian Hukum Normatif dan Empiris, Cetakan IV, Pustaka Pelajar, Yogyakarta.

Harahap, M. Yahya, (2016), Hukum Acara Perdata, Sinar Grafika, Jakarta.

Hiariej, Eddy O.S., (2015), Prinsip-Prinsip Hukum Pidana Edisi Revisi,Cahaya Atma Pustaka, Yogyakarta.

Marzuki, Peter Mahmud, (2013), Pengantar Ilmu Hukum: Edisi Revisi, Cet. Ke-4, Prenada Media, Surabaya.

Mertokusumo, Sudikno, (2006), Hukum Acara Perdata Indonesia, Liberty, Yogyakarta.

J.C. Upshaw Downs Anjali Ranadive Swienton, (2012) Ethics in Forensic Science, Academic Press, Cambdridge.

Rasyid, Roihan A., (2016), Hukum Acara Peradilan Agama, Rajawali Pers, Jakarta.

S., Salim H dan Erlies Septiana Nurbani, (2014), Penerapan Teori Hukum pada Penelitian Tesis dan Disertasi, PT Raja Grafindo Persada.

Scott, Michael dan T. Bruce Fryer, (2017), Éxito commercial (Exito comercial: prácticas administrativas y contextos culturales), Cengage, Boston.

Shidarta, (2013), Hukum Penalaran dan Penalaran Hukum Akar Filosofis, Genta Publishing, Yogyakarta.

Tim Pokja Laporan Tahunan Mahkamah Agung Republik Indonesia, (2018), Laporan Tahunan 2018 Mahkamah Agung Republik Indonesia: Era Baru Peradilan Modern Berbasis Teknologi Informasi, Mahkamah Agung Republik Indonesia, Jakarta.

\section{Journal dan karya ilmiah lain}

Aldi, Jihan Anjania, Elma Putri Tanbun, Xavier Nugraha, (2019), Tinjauan Yuridis Kewenangan Dewan Kehormatan Penyelenggara Pemilu (DKPP) Dalam Menciptakan Pemilu Yang Demokratis Di Indonesia. Jurnal Hukum De' Rechthstaat, Vol.5 No.2, Edisi Juni, hlm. 137-147.

Gupta, Raj Kumar, (1996), Justice: Unequal but Inseparate, Journal of The Indian Law Institute, Vol. 11 No. 1, Edisi Januari, hlm. 57-86. 
Insiyah, Sayyidatul, Xavier Nugraha, Shevierra Danmadiyah, (2019), Pemilihan Kepala Daerah Oleh Dewan Perwakilan Rakyat Daerah: Sebuah Komparasi Dengan Pemilihan Secara Langsung Oleh Rakyat), Supremasi Hukum: Jurnal Penelitian Hukum, Vol.28 No.2, Edisi September, hlm 164-187.

Izzati, Ratih Mannul dan Nyoman Serikat Putra Jaya, (2012), Dampak Yuridis Pemeriksaan Setempat (Gerechtelijke Plaatsopneming) Dalam Hukum Acara Pidana Dipandang Dari Aspek Pertimbangan Hukum Putusan Perkara Pidana, Law Reform, Vol. 8 No. 1, Edisi Januari, hlm. 34-57.

Maharani, Septiana Dwiputri, (2016), Manusia Sebagai Homo Economicus:Refleksi Atas Kasus-Kasus Kejahatan di Indonesia, Jurnal Filsafat, Vol. 26 No. 1, hlm 30-52.

Maulana Alfedo, Juan, Emilda Yofita, Laras Ayu Lintang Sari, (2020), Conceptualizing the Floating Court Based On E-Floating Court to Realizing Public Service the Justice System in The Fourth Industrial Revolution Era. Lex Scientia 4.1. Edisi Mei https://journal.unnes.ac.id/sju/index.php/lslr/article/view/37732, diakses tg1 29 Mei 2020.

Ngutra, Theresia, (2016), Hukum dan Sumber-Sumber Hukum, Jurnal Supremasi, Vol.11 No.2, Edisi Juni, hlm. 193-211.

Nst, Hasan Ismail Efendi, (2016) Pemeriksaan Setempat Sebagai Bahan Pertimbangan Hakim Memutus Sengketa Tanah (Analisis Putusan Nomor 345/Pdt/2015/PtMdn), Skripsi, Fakultas Hukum Universitas Muhammadiyah Malang, Malang.

Nugraha, Xavier, John Eno Prasito Putra, Krisna Darari Hamonangan Putra, (2020), Analisa Daluarsa Gugatan Pembatalan Perjanjian Akibat Adanya Penyalahgunaan Keadaan (Misbruik Van Omstandigheiden), Galuh Justisi, Vol.8 No.1, Edisi Maret, hlm 54-72.

Nugraha, Xavier, Risdiana Izzaty, Annida Aqiila Putri, (2019), Rekonstruksi Batas Usia Minimal Perkawinan Sebagai Bentuk Perlindungan Hukum Terhadap Perempuan (Analisa Putusan MK No. 22/Puu-Xv/2017), Lex Scientia, Vol.3 No.1, Edisi Juni, hlm 40-54.

Priyono, Ery Agus, (2018), Pengaruh Globalisasi Ekonomi Terhadap Perubahan Peraturan Bidang Perjanjian di Indonesia, Diponegoro Private Law Review, Vol.3 No.1, Edisi Juni, hlm. 248-260.

Rawinarno, Tjahyo, (2017), Otonomi Daerah dan "Amandemen Kedua" UUD 1945, Journal of Government, Edisi Juli, Vol. 3 No. 1, hlm. 281-292.

Sari, Putu Prasmita dan I Gusti Ngurah Parwata, Perlindungan Hukum Para Pihak Dalam Perjanjian Bisnis Franchise, Kertha Semaya 5.5. https://ojs.unud.ac.id/index.php/ kerthasemaya/article/download/24613/15864, diakses pada 1 Juni 2020

Siegel, Reva B., (2019), The Constitutionalization of Disparate Impact - Court-Centered and Popular Pathways, California Law Review, Vol. 106, No. 661, Edisi Januari, hlm. 2001-2016.

Slamet, Sri Redjeki, (2013), Tuntutan Ganti Rugi dalam Perbuatan Melawan Hukum: suatu Perbandingan dengan Wanprestasi, Lex Jurnalica, Vol. 10 No. 2, Edisi Agustus,hlm. 107-120. 


\section{Website}

Kusumasari, Diana, Arti Gugatan Dikabulkan, Ditolak, dan Tidak Dapat Diterima, https https://www.hukumonline.com/klinik/detail/ulasan/cl3157/putusanhakim-dalam-acara-perdata/ diakses pada tanggal 1 Juni 2020.

Shietra, Herry, Pemeriksaan Setempat oleh Hakim dalam Pemeriksaan Sengketa Tanah, https https://www.hukum-hukum.com/2017/10/pemeriksaan-setempat-olehhakim-sengketa-tanah.html diakses pada tanggal 1 Juni 2020.

Tribunnews, Mengenal Lebih Jauh KBBI, Dari Sejarah Sampai Proses Masuknya Sebuah Kata, diakses pada tanggal 1 Juni 2020.

\section{Peraturan Perudang-undangan}

Undang-Undang Dasar Negara Republik Indonesia Tahun 1945.

Burgerlijk Wetboek, Staatsblad Nomor 23 Tahun 1847.

Herzien Indonesis Reglement, Staatsblad Nomor 16 jo. 57 Tahun 1848 dan Staatsblad Nomor 31,32, dan 44 Tahun 1941.

Rechtsreglement Buitengewesten, Staatsblad Nomor 227 Tahun 1927.

Wetboek op de Burgerlijke Rechtvordering, Staatsblad Nomor 52 Tahun 1987.

Surat Edaran Mahkamah Agung Nomor 7 Tahun 2001 tentang Pemeriksaan Setempat 